\title{
Zuses. \\ Lewis and Clark's Observations of Geomorphology and Hydrology
}

Meriwether Lewis and William Clark are famous as explorers, but they were also scientists who led one of the first scientific expeditions, Corps of Discovery, across the United States from Pennsylvania to the Pacific Ocean. Both men were keen observers and provided early insights into the yet unnamed fields of geomorphology and hydrology. They made geomorphic observations when they described the rivers, the processes that form them, and the adjacent landforms. They made hydrologic measurements (water level, temperature, and velocity) of many streams and rivers. Lewis and Clark recorded extensive observations related to biology, botany, ethnology, meteorology, phenology, and zoology as well as geomorphology and hydrology. This fact sheet provides some of their written observations and measurements (given in italics), taken from Moulton's (1983-93) eight annotated volumes of the journals of Lewis and Clark.

\section{Geomorphology Maps}

Clark made some of the first accurate maps of the rivers and the surrounding country (fig. 1). The maps were based not only on personal observations and measurements but also on information they obtained from the native people. Clark recorded the compass bearing and distance for each reach of river traversed during the day. The distances he gives are comparable to those that the Missouri River Commission published about 90 years (1892-95) later (fig. 2).

\section{Meanders}

Lewis and Clark commented on river processes, which they observed as they traveled. For example, on the Missouri River about 100 miles above the Platte River in Nebraska, Clark noted,

"...I have observed a number of places where the River has onced run and now filled, or filling up \& growing with willows \& Cottonwood ..." 11 August 1804,

and 50 miles above Big Muddy Creek in Montana Lewis wrote,

"...traces of the ancient beds of the river are visible in many places through the whole extent of this valley..." 3 May 1805.

They collected data from which the "crookedness" or sinuosity (river distance/valley distance) can be calculated. On the Jefferson River in 1805, Clark recorded the number of bends, the river distances, and the valley distances. Based on his data, the wavelength or distance between two bends of a meandering river, is about 9.4 times the river width, which is similar to an empirical relation for rivers published about 150 years later.

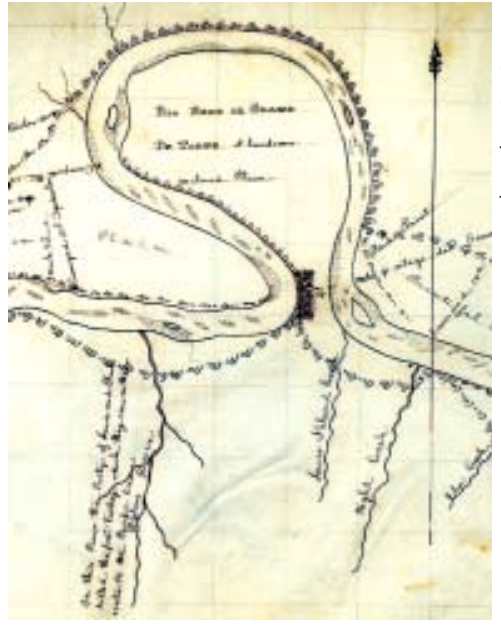

Figure 1. Maps. Clark recorded many detailed facts on his maps (courtesy of the Joslyn Art Museum) and in his journals and field notes. His journal entry for 20 September 1804 contains this note:

"...Mes. To a Cedar hill on the $L$. $S$ in a bend opposite the Gorge of this bend where the river is only $11 / 4$ mile across \& 30 Miles around..." 20 September 1804 and later added "... below the bend is a butifull inclined Plain in which there is great numbers of Buffalow, Elk \& Goats in view feeding..." 21 September 1804.

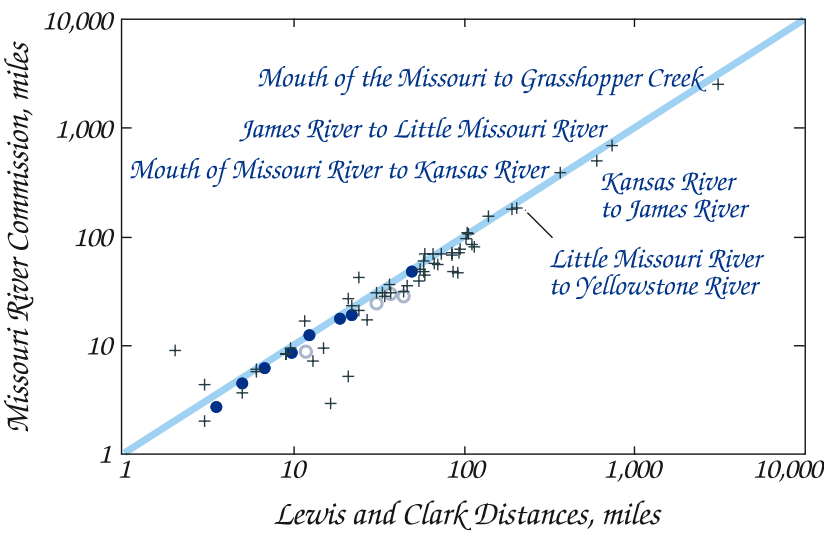

Figure 2. River Distances. Lewis and Clark measured the length of each reach of the Missouri River as they traveled up the meandering river. Their measured reach lengths are similar to those published by the Missouri River Commission between 1892 and 1895 in places where the river was confined in canyons, but different in meandering reaches where the river could either increase or decrease its length by natural processes.

\section{Landscapes}

Lewis and Clark recorded their direct observations of the plains, hills, and mountains through which they passed.

“...from this hight we had a most beatifull and picturesk view of the Rocky mountains which wer perfectly covered with Snow...this was an august spectacle and still rendered more formidable by the recollection that we had them to pass ..." 12 June 1805.

The two men often commented on specific geomorphic features within the larger landscapes. While descending the Ohio River, Lewis wrote this description of flood plains and terraces before any descriptions of these types of geomorphic features were published in the scientific literature. He refers to terraces as bottoms:

“... on each side of the river there are three banks, or suddon rises ... the fist bank or that which the river washes is generally from twenty to twentyfive feet...; this bottom which is certainly the richest land from it's being liable some times to be overflowed is not esteemed so valuable as the second bottom - The second bottum usually rises from twenty five to thirty feet above the first and is allways safe or secure from inundation; ... what is called the third bottom is more properly the high benches of the large range of hills before noticed..." 2 September 1803. 


\section{Channel-Scale Geomorphic Features}

Riffles, rapids, falls, sandbars, point bars, and braided streams generally are mentioned as obstacles to the expedition. For example, while descending the Ohio River in the fall of 1803 when the Ohio River was especially low:

".... [s] truck on a riffle which we got over with some difficulty and in the distance of two miles and a half passed 4 others three of which we were obliged to drag over with horses; the man charge me the exorbitant price of two dollars for his troubles..." 6 September 1803.

At the Great Falls of the Missouri River Clark, took time to measure the falls (fig. 3). Sandbars were numerous on the Missouri and were mentioned often as the party labored upriver. However, during the return trip in 1806, they traveled down the Missouri River after the summer peak runoff, and Clark commented on how the river had changed:

"....in places where there was Sand bars in the fall 1804 at this time the main Current passes, and where the current then passed is now a Sand bar-Sand bars which were then naked are now covered with willow Several feet high..." 20 August 1806.

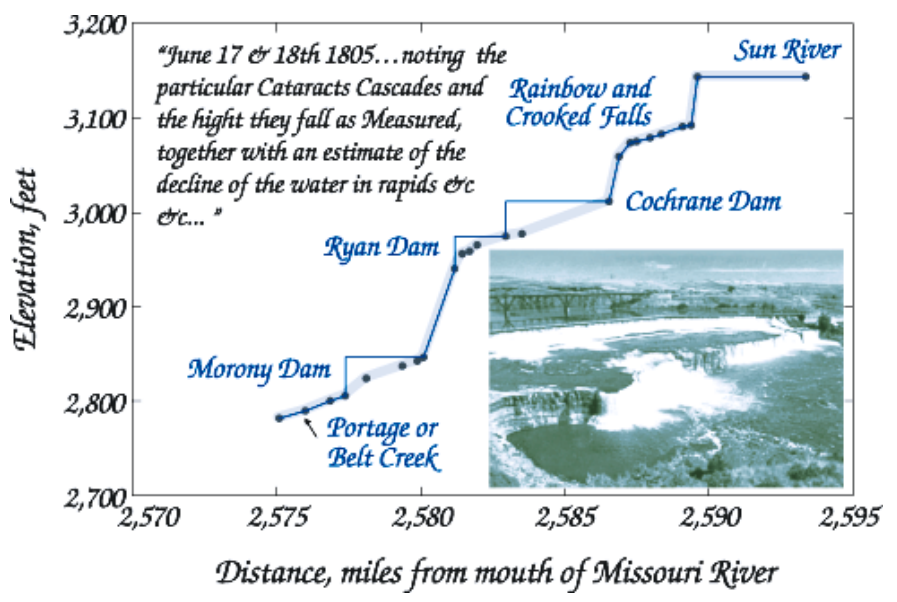

Figure 3. The Great Falls of the Missouri River. It took the expedition about a month (June 16 to July 14,1805$)$ to portage around these falls. Clark made the original horizontal measurements in poles ( 16.5 feet) and the vertical measurements in feet. These have been plotted to show the profile of the Great Falls in 1805. The total horizontal distance was 14.83 miles with a total drop of $360 \mathrm{feet}$, or an average slope of 0.005 . Superimposed upon Clark's profile of the Great Falls are the approximate locations of four dams. The largest fall, 93.75 feet high according to Clark, is now part of the Ryan Dam. Crooked and Rainbow Falls were measured by Clark to be 34 and 47.67 feet high. They can still be seen today (photograph from National Park Service).

The braided character of the Missouri was first noted on October 6,1804 ,

“...we made Severl. Attempts to find the main Channel between the Sand bars...we have been obgd to hunt a Chanl. For Some time past the river being devided in many places in a great number of Chanels..."

and along a braided reach in the Rocky Mountains, the beaver's role as a geomorphic agent was mentioned:

"...the river in many places among the clusters of islands is constantly changing the direction of such sluices as the beaver are capable of stoping or of $20 \mathrm{yds}$. in width. this anamal in that way I beleive to be very instrumental in adding to the number of islands with which we find the river crouded ..." 24.Julv 1805

\section{River Processes}

Lewis and Clark described many examples of the geomorphic processes that change rivers and landscapes. Bank erosion was reported primarily during periods when the river was rising (fig. 4). Eolian transport was first mentioned near the Big Sioux River:

“...The Wind blew hard... and raised the Sands off the bar in Such Clouds that we Could Scercely See this Sand being fine and verry light Stuck to every thing it touched, and in the Plain for a half a mile the distance I was out every Spire of Grass was covered with the Sand or Dust..."23 August 1804.

Figure 4. Bank erosion and point bar deposition. Lewis and Clark observed and described this geomorphic process, which is recognized today as a mechanism that nat-urally maintains the character of meandering river:

"...In every bend the banks are falling in from the Current being thrown against those bends by the Sand points which inlarges ...Sand and Clay easily melts and Slips into the River, and the mud mixes with the water \& the Sand is washed down and lodges on the points..."5 August 1804.

In this aerial view of the Powder River in southeastern Montana, the river is flowing down the page, and the channel is about 50 yards wide.

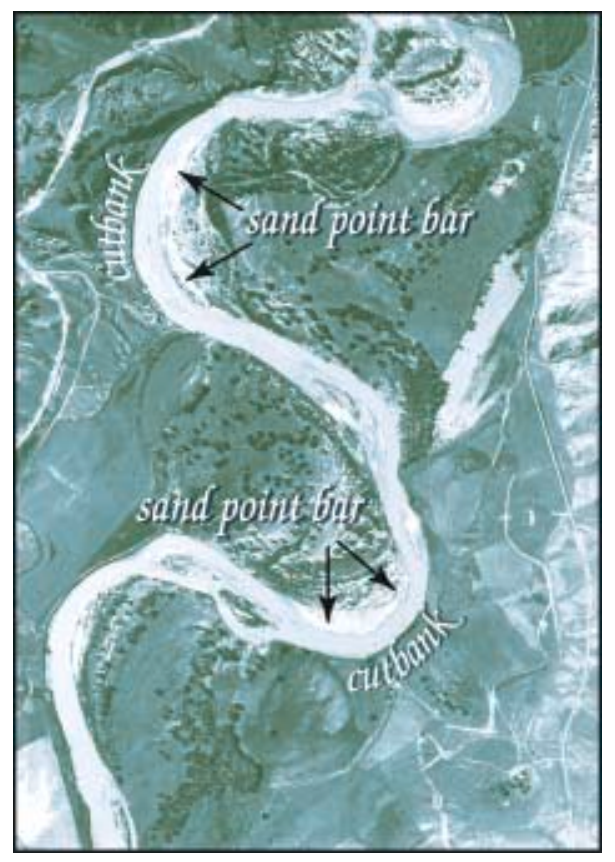

Lewis wrote this description of suspended-sediment transport: “...The river Platte does not furnish the Missouri with it's colouring matter, as has been asserted by some... The water of the Platte is turbid at all seasons of the year, but it is by no means as much so, as that of the Missouri; the sediment it deposits consists of small particals of white sand, while that of the Missouri is composed principally of a dark rich loam in much greater quantity..." Fort Mandan Miscellany.

Clark made this quantitative measurement of the suspendedsediment concentration downstream from the Kansas River:

"...The water we Drink, or the Common water of the missourie at this time, contains half a Comn Wine Glass of ooze or mud to every pint..." 21 June 1804.

Bedload transport was described by Lewis at the mouth of the Platte:

“...The bed of the river Platte is composes almost entirely of white sand, the particles of which, are remarkably small and light; these collecting, form large masses, which being partially buoyed up, are hurryed along the bottom by this impetuous torrent, with irresistible force; sometimes obstructed by each other, suddonly stop; and form large sandbars in the course of a few hours, which are again as suddenly dissipated to form others, and to give place perhaps to the deepest channel of the river..." Fort Mandan Miscellany. 
Figure 5. River characteristics. The area of the circle is proportional to the channel width. The color of the large circle approximates the color of the water (gray indicates no color was mentioned in the journals). Descriptions of the bed material are determined by the position of the solid black circle within the black triangle. The example in the upper right indic ates a width of 500 yards, a yellow water color, and bed material that is mostly sand with some gravel and some mud.

\section{Co}

Hydrology

\section{River Characteristics and Runoff}

Lewis and Clark described the navigability, color, width, and type of bed material for many of the rivers and streams (fig. 5). In addition, they often noted the air and water temperature:

"... Thermometer in the air to stand at $71^{\circ}$ water $73^{\circ}$ - the fogg continued even with small difference between the temperature of the air and water..." 6 September 1803.

and recorded the water level or stage of the river each day (fig. 6). Water chemistry was also mentioned:

“...this River is about $30 y d s$. wide, and has So many Licks \& Salt Springs on its banks that the Water of the Creek is Brackish, one Verry large Lick is $9 \mathrm{~ms}$. up on the left Side the water of the Spring in this Lick is Strong as one bushel of the water is said to make 7 lb. of good Salt..." 6 June 1804.

Lewis and Clark, like most Americans of that time, were accustomed to Eastern rivers that flow all year and in which the flow usually increases downstream. Dry channels, in what is now Montana, were unexpected:

"...today we passed the bed of the most extraordinary river that I ever beheld. it is as wide as the Missouri is at this place or 1/2 a mile wide and not containing a single drop of running water; some small standing pools being all the water that could be perceived..." 9 May 1805.

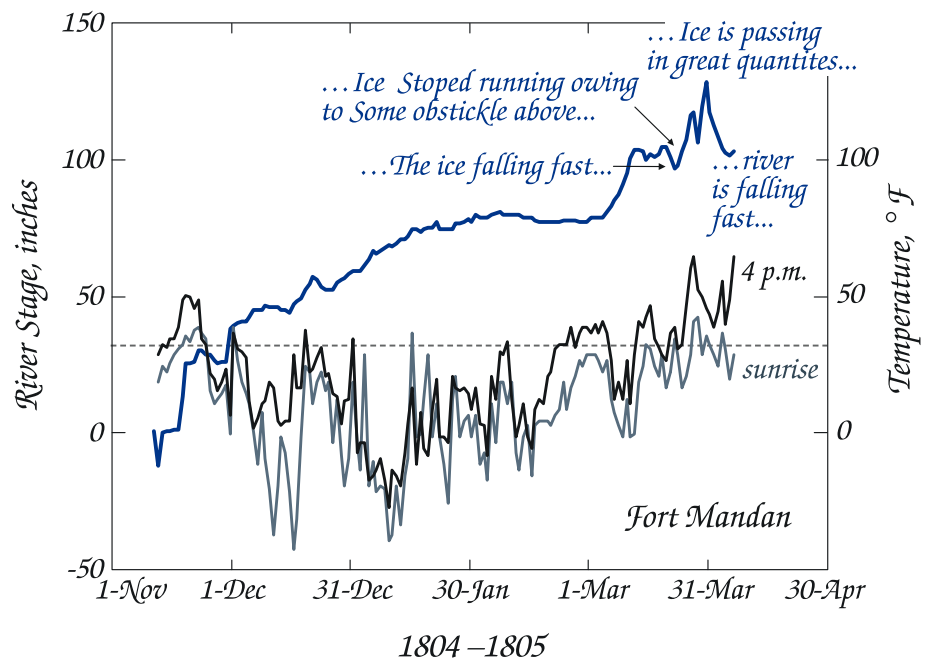

Figure 6. River stages and air temperatures. Lewis and Clark measured these hydrologic variables while they wintered at Camp Dubois near St. Louis, Missouri, in 1804-05 and at Fort Mandan near Bismarck, North Dakota, in 180506 . Temperatures were measured every day at sunrise and at 4 p.m.

\section{Hydraulic Geometry}

Lewis and Clark measured the channel widths of virtually every stream or river they encountered. They made the important distinction between flood-plain width, bankfull width, and the width of the water surface:

"...this river whin full is 90 yards wide the water is at this time Confined within 20 yards..." 7 October 1804.

They also noted seasonal effects:

“...passed Dearborne's river at 3 m...it appears to spread over it's bottoms at certain seasons of the year and runs a mear torrant tearing up the trees by the roots which stand in it's bottom..." 18 July 1805.

Lewis and Clark made about 275 width measurements of rivers, streams, and creeks ranging from 4 to 875 yards. Some of the larger rivers (Missouri, Yellowstone, and Columbia) were measured in several locations. Their data can be plotted to show a hydraulic geometry relation between the width of a river at the mouth and drainage area of that river (fig. 7).

\section{Velocity Measurements}

Many journal entries give qualitative measures of the velocity of the current:

"...the water excessively rapid ...the Currents verry Swift ...the current exceedingly rapid..." 15 May to 15 June 1804.

But on June 17, 1804, Clark made quantitative measurements of the velocity, which he continued to make at different locations along the Missouri River (see Moody and Meade, in press, for more details). Although they did not have instruments to measure turbulent velocities, Lewis's words accurately describe turbulence in open-channel flow:

"...The steady, regular, and incessant velocity of this stream, is perhaps unequaled by any on eath; notwithstanding it's great rapidity the surface of the water continues smooth, except when occasionally interrupted by a boiling motion, or ebullition of it's waters... in this manner the water, is seen to rise suddenly many inches higher than the common surface, then breaking with a 
rappid and roling motion extends itself in a circular manner in every direction arround interrrupting the smooth, tho'rappid surface of the water for many yards... " Fort Mandan Miscellany.

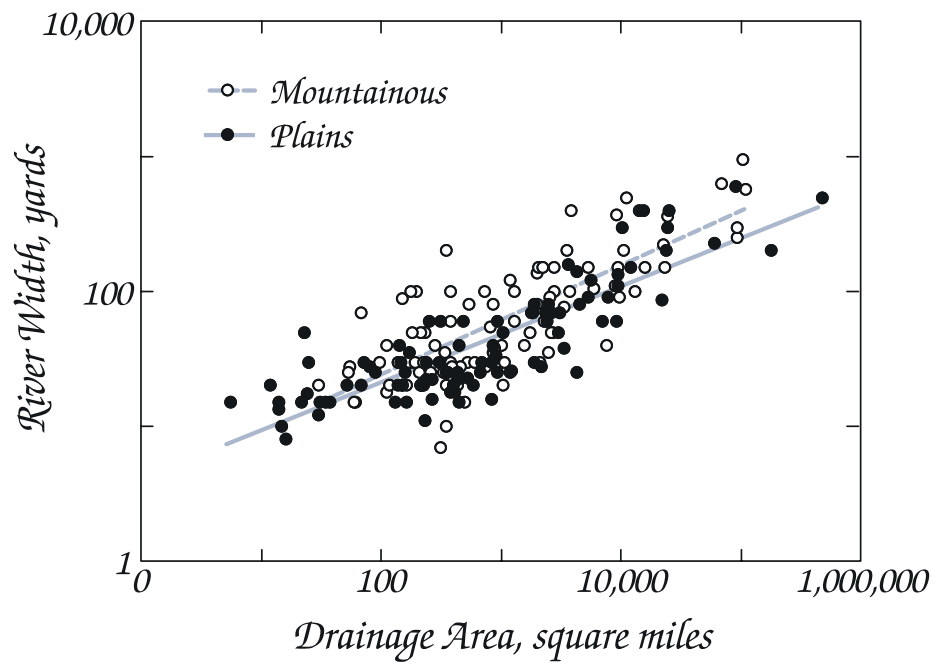

Figure 7. Hydraulic Geometry. The 191 measurements of river width represent a subset of all the channel widths recorded by Lewis and Clark. For these measurements, the drainage areas were determined by the authors of this fact sheet. The relation between river width, and the drainage area, is shown for plains rivers (downstream from the Yellowstone River) and for mountainous rivers (upstream from the Yellowstone River and some tributaries to the Columbia River). The relations are basically the same as those relations published about 150 years later by other scientists.

\section{Changes in 200 Years}

Dams for navigation, flood control, agriculture, and water supply coupled with navigation improvements have changed the rivers traveled by Lewis and Clark. Nineteen major dams now control the Ohio River, six dams control the main-stem Missouri River, and eight dams control the Columbia and Snake Rivers traveled by the Lewis and Clark expedition. Many smaller dams have been built as stock ponds and water-supply reservoirs. Reservoirs now cover many of the meanders, riffles, rapids, and falls encountered by the Corps of Discovery. Dams regulate the hydrologic regime and biological communities downstream, and

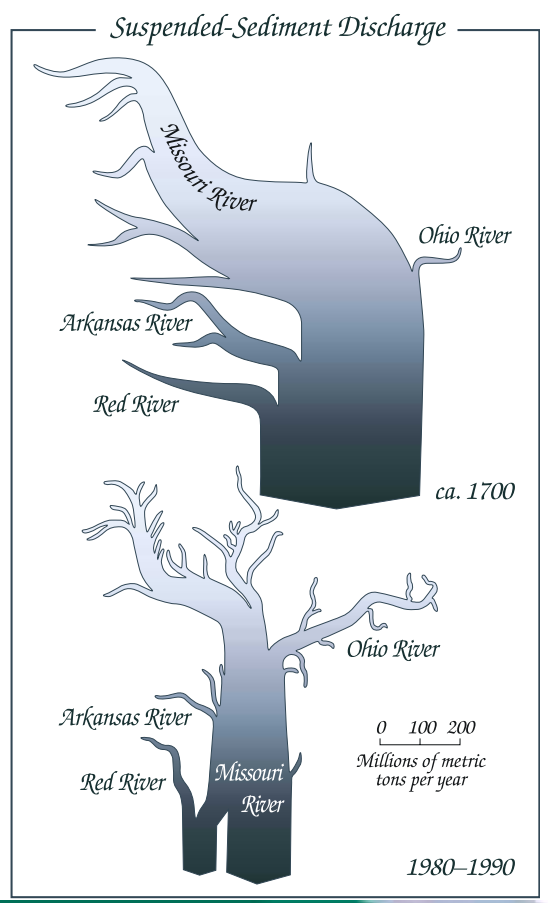

sediment changes. The sediment discharge was estimated to have been about 300 million metric tons per year during the time of the Lewis and Clark expedition. This sediment built and replenished the coastal area of Louisiana surrounding the Mississippi River. Today, 200 years after the expedition, as a consequence of dams, channelization projects, the lower part of the Missouri River carries only 80 million metric tons per year. they trap sediment (fig. 8). Sediment that was once "thrown out" by tributaries has been reduced, and a "river full of Sand bars and riffles" has largely disappeared in many places. Many navigation improvements take the form of channelization and bank stabilization. These improvements have shortened the rivers, decreased the water-surface area, and decreased the number of sandbars and islands (fig. 9). These changes have altered the landscape and ecology of the rivers and lands explored, measured, and observed by Lewis and Clark.

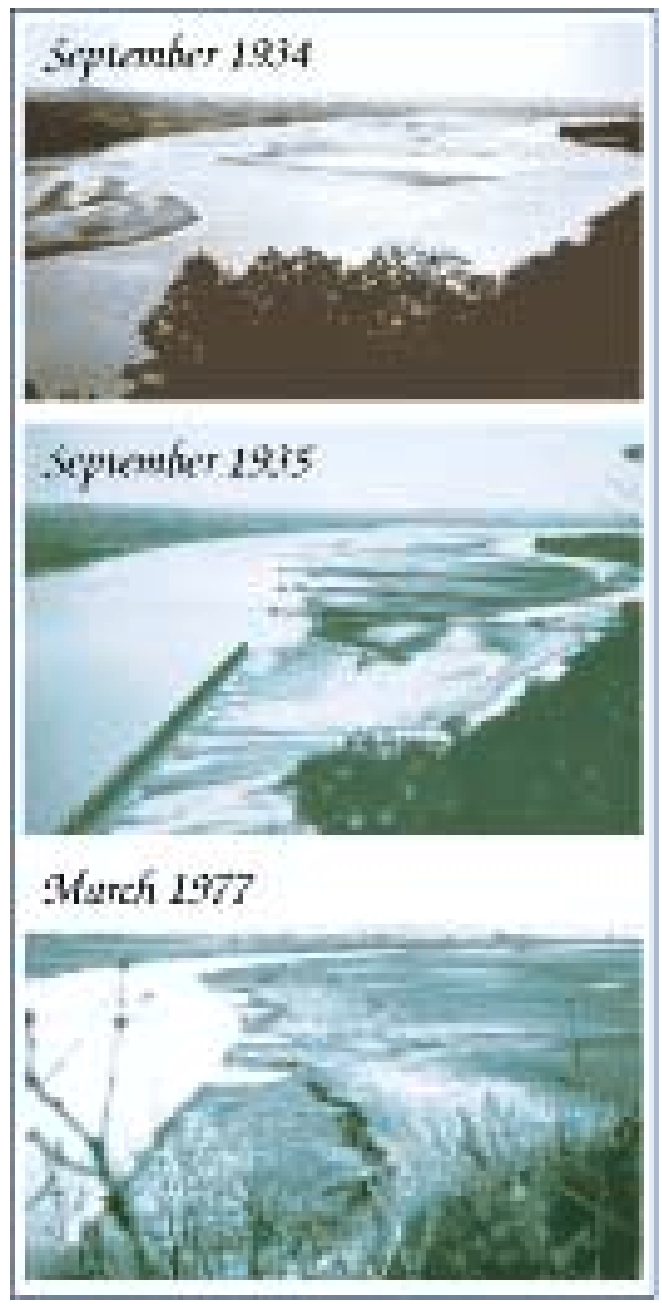

Figure 9. Channel changes. Channelization and dams have resulted in the encroachment of vegetation into the channel. These photographs collected by Norm Stuckey were taken before and after pile dikes were constructed on the Missouri River and clearly show the increase in flood plain adjacent to the channel, the decrease in width of the channel, and the change in the natural character of the channel. bank stabilization, and

\section{References cited:}

Moulton, G.E., ed., 1983-93, The journals of the Lewis \& Clark expedition, 8 volumes: Lincoln, University of Nebraska Press. and measurements of geomorphology and hydrology and changes with time: U.S. Geological Survey Circular 1246.

\section{For further information please contact:}

John A. Moody - jamoody@usgs.gov, (303) 541-3011

USGS Branch of Regional Research, Central Region

P. O. Box 25046, MS418

Denver Federal Center

Lakewood, CO 80225-0046

(303) 236-5021
Moody, J.A., and Meade, R.H., in press, Lewis and Clark's observations 